\title{
Analysis and Simulation of The Effects That Cause Fatigue in the Frame Structure 308 of the Uh-60 Helicopter
}
Análisis y simulación de los efectos de fatiga en la estructura del helicóptero UH-60 308

\section{Análise e simulação dos efeitos que causam fadiga na estrutura 308 do helicóptero UH-60}

\author{
Jimmy Anderson Florez Zuluaga ${ }^{1}$ \\ Andrés Márquez Atrio ${ }^{2}$ \\ Andres Ayala Angel ${ }^{3}$ \\ Carlos Jahir Carreño Hernández ${ }^{4}$
}

Received: June $3^{\text {rd }}, 2019$

Accepted: August $5^{\text {th }}, 2019$

Available: September 16 ${ }^{\text {th }}, 2019$

How to cite this article:

J.A. Florez Zuluaga, A. Ayala Angel, and C. J. Carreño Hernández, "Analysis and Simulation of The Effects That Cause Fatigue in the Frame Structure 308

of the Uh-60 Helicopter," Revista Ingeniería Solidaria, vol. 15, no. 3, 2019. doi: https://doi.org/10.16925/2357-6014.2019.03.12

Artículo de investigación. https://doi.org/10.16925/2357-6014.2019.03.12

1 Colombian Air Force-Aerospace Technology Development Centre for the Defense - CETAD. Rionegro, Colombia. ORCID: https://orcid.org/0000-0002-0426-1000

E-mail: jimmy.florez@fac.mil.co

2 Colombian Air Force-Aerospace Technology Development Centre for the Defense - CETAD. Rionegro, Colombia. ORCID: https://orcid.org/0000-0002-0710-676X

E-mail: andres.marquez@fac.mil.co

3 Colombian Air Force-Aerospace Technology Development Centre for the Defense - CETAD. Rionegro, Colombia. ORCID: https://orcid.org/0000.0002.7570.1376

E-mail: ayala.cetad@epfac.edu.co

4 Colombian Air Force-Aerospace Technology Development Centre for the Defense - CETAD. Rionegro, Colombia. ORCID: https://orcid.org/0000-0002-2939-8775

E-mail: carlos.carreno@fac.mil.co 


\section{Abstract}

Introduction: This is a product of the research "Study of operational maneuvers for the detection of structural fatigue in the UH-60 helicopter", developed through COLCIENCIAS project number 56742, at the Colombian Air Force-Aerospace Technology Development Centre for the Defense - CETAD, during 2017-2019.

The objective of the project was to design and develop a system that would allow studying the strain generated by operational maneuvers and the relation between them and the structural fatigue of frame 308 of the UH- 60 .

Methodology: The project was based on the integration of strain and vibration data from the helicopter's frame 308 instrumentalization to development a relevant simulation and analysis.

Results: In the first instance, the data collection was synchronized with the flight maneuvers, identifying the strain generated in each position. This helped establish the range of the loads on the beam during operational maneuvers.

Conclusions: In this project, a series of sensors and data acquisition and recording devices were integrated into the aircraft in order to identify the maneuvers that generate strain in frame 308 , based on the use of the manufacturer's manuals and engineering processes.

Originality: This document formulates data from possible situations for the first time, because there is no history of literature on the study, characterization or materials on frame 308 of the UH-60 helicopter.

Limitations: Insufficient public information about the UH-60 aircraft.

Key words: Keywords: UH-60, simulation, frame 308, Dot cloud, XFEM, material characterization, fatigue, damage evolution, structural efforts

\section{Resumen}

Introducción: El presente es producto de la investigación "Estudio de las maniobras operacionales para la detección de fatigas estructurales en el helicóptero UH-60", desarrollado a través del proyecto de Colciencias 56742, en el Centro de Desarrollo Tecnológico Aeroespacial para la Defensa - CETAD de la Fuerza Aérea Colombiana, durante 2017 al 2019.

Objetivo: El objetivo del proyecto fue diseñar y desarrollar un sistema que permitiera estudiar los esfuerzos que generan las maniobras operacionales y que pueden ocasionar fatigas estructurales en el frame 308 de la aeronave $\mathrm{UH}-60$.

Metodología: El proyecto se basó en la integración de datos de la instrumentalización del marco 308 que detectan la tensión y las vibraciones sufridas por el helicóptero, para el desarrollo de la simulación y el análisis.

Resultados: En primera instancia la recolección de datos sincronizados con las maniobras de vuelo, identificando los esfuerzos que se generan en cada posición, lo que permitió establecer los rangos de las maniobras operacionales, lo cual ayuda a representar cargas de la viga.

Conclusiones: En este proyecto se integró en la aeronave una serie de sensores y dispositivos de adquisición e grabación de datos con el fin de encontrar aquellas maniobras que generen esfuerzos en la viga 308, partiendo del uso de los manuales del fabricante y de los procesos de ingeniería.

Originalidad: Se formulan por primera vez basados en datos de posibles situaciones, ya que no existen antecedentes de trabajos publicados sobre el estudio, caracterización y materiales sobre la estación 308 del helicóptero UH-60.

Limitaciones: Insuficiente información pública sobre la aeronave UH-60.

Palabras clave: UH-60, simulación, frame 308, Nube de puntos, XFEM, Caracterización del material, Fatiga, Evolución del daño, esfuerzos estructurales. 


\section{Resumo}

Introdução: o presente estudo é produto da pesquisa "Estudo das manobras operacionais para a detenção de fadigas estruturais no helicóptero UH-60", desenvolvido por meio do projeto de Colciencias 56742, no Centro de Desenvolvimento Tecnológico Aeroespacial para a Defesa (CETAD) da Força Aérea Colombiana, de 2017 a 2019. Objetivo: o objetivo do projeto foi desenhar e desenvolver um sistema que permitisse estudar os esforços que as manobras operacionais geram e que podem ocasionar fadigas estruturais na estrutura 308 da aeronave UH-60.

Metodologia: o projeto foi baseado na integração de dados da instrumentalização da estrutura 308 que detectam a tensão e as vibrações sofridas pelo helicóptero para o desenvolvimento da simulação e da análise.

Resultados: na primeira instância, a coleta de dados sincronizados com as manobras de voo, para identificar os esforços gerados em cada posição, permitiu estabelecer os intervalos das manobras operacionais e isso ajuda a representar cargas da viga.

Conclusões: neste projeto, uma série de sensores e dispositivos de aquisição e gravação de dados foi integrada na aeronave com o objetivo de identificar as manobras que geram esforços na viga 308, a partir do uso dos manuais do fabricante e dos processos de engenharia.

Originalidade: são formulados pela primeira vez com base em dados de situações possíveis, já que não existem antecedentes de trabalhos publicados sobre o estudo, a caracterização e os materiais sobre a estação 308 do helicóptero UH-60.

Limitações: informação pública insuficiente sobre a aeronave UH-60.

Palavras-chave: UH-60, simulação, estrutura 308, nuvem de pontos, método dos elementos finitos estendidos, caracterização do material, fadiga, evolução do dano, esforços estruturais.

\section{INTRODUCTION}

Aircraft may be modified or have installations like cameras, cranes, radars, etc. installed by the aircraft manufacturer for specific functions. These modifications can affect the initial aerodynamics calculations, usage, lifetime, and other factors like material selection. These modifications may result in a different lifespan for one or more components. These modifications should be considered in aircraft maintenance, monitoring and life sheet processes

This document describes development of a high-precision simulation in order to characterize frame 308 of a UH-60 that, in some cases, have been cracked. This procedure has been developed by the Colombian Air Force to characterize the part and the stresses suffered during the operation of the aircraft. The simulation model will be used as part of a preventive, predictive and aviation safety maintenance process. The simulation used Extended-Finite-Elements (XFEM). It involved analysis of structural cracking and fatigue in the main beam. The material was characterized using the ASTM-E8 standard and specimens were tested with traction equipment. These two methods yielded a significant amount of information about the material of the aircraft. Component modelling was accomplished using a surface survey of the aircraft with 
a 3D scanner. The 3D model was then subjected to simulated loads using XFEM. The interaction and deformation behavior of the elements of the main beam were analyzed under its operating conditions. This document took into account maintenance criteria in the aerospace industry and best practices based on the manufacturer's and operator's manuals. This was done in order to simulate the conditions which some structural components of the aircraft are subjected to.

\section{STATE OF THE ART}

In many cases, aircraft manufacturers will deliver to the market an aircraft meant for general use. This is the case for the UH-60 Black Hawk which is a twin-engine load-carrying utility helicopter and tactical transport that was designed in the 1970s. In the aeronautical industry, an aircraft can undergo modifications in which new parts are integrated that were not installed or designed by the manufacturer. These can include but are not limited to cameras, cranes, radar, fixed-wings, antennas, tanks, armament, sensors, LIDAR and on-board equipment. These modifications could make the initial aerodynamic calculations from the manufacturer dissimilar to the aircraft and change the lifetime of one or more parts as described in the United States Army Procedures Conference [1], [2] and more recently in [3], [4].

Aeronautical maintenance is important and delicate. It must have traceability of processes, spare parts, pieces and the training of related personnel as seen in [5], [6] as it should attempt to minimize the probability of failure.

Aircraft used by the State security forces are generally reequipped or reconfigured to suit their mission. The mission could be transport, executive Transport (VIP), search and rescue, gunships, intelligence, or others [7]. Some configurations are described in [8], [9] which are used by the police and as advanced tactical control systems.

These configurations involve modifications that should be taken into consideration when doing preventive maintenance, repairs, monitoring and adding information to the life sheet of the aircraft. When information is being gathered about the aircraft for its life sheet and maintenance sheet, there are different application procedures and technologies which are described in [1], [2],[5],[10] - [11]. These sources detail some of the processes developed to ensure the usability of the steering gear. For example, [1] describes the integration of systems of weapons in helicopters. In [2], the authors describe optical technologies used to analyze materials and the use of electronic microscopes in maintenance. [2] also discusses the application of models to diffuse the simulation. [12] analyses degradation of aluminum structures due to corrosion and 
discusses the application of statistical techniques to Kalman filters in predictive and preventive maintenance processes in order to predict failure in some parts.

[11] explains the advantages of the simulation and modelling applied to the maintenance processes of different subsystems.

Maintenance processes are strict and must have traceability of all procedures as they are a part of air safety; the main priority when operating aircraft.

The Air Force uses maintenance processes that are developed with high-quality standards which integrate technological advances with solutions to previous failures.

In some of the maintenance processes, microfractures were found in one of the main beams of the UH-60. Because of this, the Centre for Technological Development presented the possibility that a system could be developed that would identify the reasons for the presence of these fractures. To this end, it was desirable to identify the degree of impact that maneuvers, in the profile described in [13], had on frame 308. This was desirable, because frame 308 is a fundamental structural pillar of the UH-60.

The micro-fractures were detected primarily in areas of subjection with other parts of the structure. In addition to their presence in attachment points and the fuse beam, micro-cracks are also the cause of stress concentration in holes and edges. Micro-cracks near holes and edges are detected by widely disseminated practices in the aeronautical maintenance sector which are detailed in [14] and [15] - [16]. These practices are also used to detect anomalies or damage to the structure. Currently, the most used inspection types are Non-Destructive Testing (NDT) [17] and Detailed Visual Inspections (DVI).

The military forces of other countries have carried out various procedures that identify structural damage. They have also been making technological advances by developing tailor-made solutions. These solutions use integrated software with sensorics, focused on monitoring crack propagation in aerospace structures in which particular cases of deformation and fatigue arise; this research focuses on structural health monitoring [18] and current structural state [19] [20]. The previously described concepts will be applied, in this work, to analyze the behavior of elements that converge in the main structure of the $\mathrm{UH}-60$.

The first step in developing this research was to create a model of frame 308. This was done using a surface construction with a 3D scanner. In addition to this, we executed the processes to characterize the material, as found in [21] [22]. 3D modelling of the structural elements was accomplished with Dassault Systems ${ }^{\circledR}$ Catia CAD software and the stress simulation was done using the finite element method in Dassault Systems ${ }^{\circledR}$ Abaqus. An assembly was also generated which included all of the structural components and properties [23] associated with frame 308. 
The results obtained from the tensile test of the prepared specimens [21] for this procedure made it possible to determine the permissible limit loads [23] of the structure of the aircraft. These limits change depending on the maneuvers that are performed in the operations the aircraft is designed for. The aircraft's technical manuals were used as reference points in order to comply with the protocols established by the aircraft manufacture and operator. These manuals were: the structure of the aircraft [24], maintenance manual [25] and the Manual for transporting dangerous goods of the Colombian Air Force [26]. The results obtained from the analyses allowed for the unification of the selected factors that compromise the integrity of the structure of the aircraft. Additionally, it presents the maintenance personnel with the ability to take preventive measures related to the inspections [18] and based on the frame condition. At the same time, the results can be used to create helicopter reports that depend on the flight maneuvers and the airframe availability. These ensure the integrity of the aircraft.

\section{PROBLEM DESCRIPTION}

During the maintenance processes, inspectors perform different types of tests and checks. These vary according to the equipment, type of maintenance, planning, number of flight-hours, environment, stresses, vibrations, technical personnel, and other factors. For structural units in accordance with [27], [28] and, more specifically in this analysis, frame 308 , the critical points are the fixing points of the structure.

The maintenance technicians support this work. The area of interest was analyzed on several available structures. Some areas contained micro-cracks. These damaged areas were demarcated, and the characteristics of these damages were classified. It was based on the results of an earlier project called "THE UH-60 HELICOPTER STRESS ANALYZER". When analyzing this project, it was found that although the process of acquiring information about stresses was in accordance with the requirements, there was no comparison data. For example, there was no data comparing the existing deformations in a beam after a certain number of flights. Although there was data for the stresses caused by the flight, there was no valid digital information about the maneuver that caused this deformation.

Following this process, state of the art advances related to the study of structural health monitoring in aeronautical and aerospace structures were reviewed [29]. This review looked for information about similar problems and the procedures used to solve them. It found that there are two commonly used models, and that the type of simulation depends on the amount of information available. 
The manufacturer's manuals, other manuals and established procedures, such as [30], [31], [32], were used as an initial basis for the development of research about factors which influence frame cracking and fatigue.

The next step was to determine the physical, chemical and mechanical properties of the material of frame 308 that forms the beam of the UH-60 aircraft [21] [22] [33]. This was done to qualify and quantify the properties of the material and to produce results that can be compared with the results obtained by analysis and the resistance of the materials as described in [23].

To improve the results obtained in the previous project and gather more information for the simulation, a surface construction of the frame was made with a 3D scanner. The scanner ("Scanner Tarsio 3D") was used to get the form of the frame. This work developed a model of frame 308 by using a digital cloud of points for the frame with zero flight hours (new) and after 7500 flight-hours. This study can be used to develop different simulations and take measurements to study the effect of stresses after the frame is flown for a variable number of hours.

However, it is challenging to acquire in-flight data on the deformations and stresses of the structure in of each of the flights maneuvers. To have a real-time synchronization of the in-flight stresses and the maneuvers that provokes these stresses, it was suggested that an automatic pilot with sensors for the three axes could be used. In addition to this, a flight parameter recorder, consisting of a camera synchronized with the autopilot that would provide more information on the position of the aircraft in each situation, could be used. This equipment would be installed in the cabin of the aircraft and integrated with a data recording system using a CX22B system of HBM. This data acquisition system, shown in Figure 1a, would be able to record the flight parameters including the aircraft position, flight profile, maneuvers loads and related stresses on the structure of the UH-60 aircraft. 


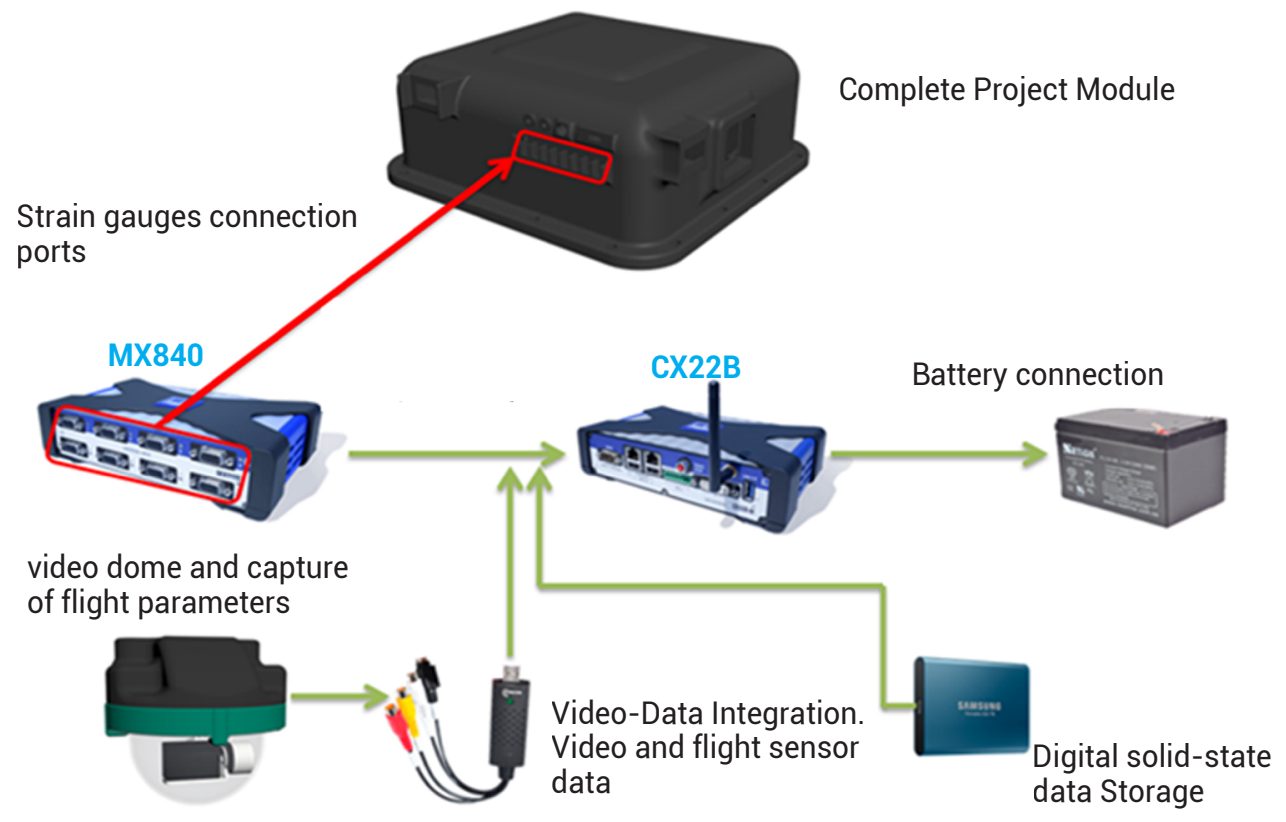

Figure 1a. Data acquisition operational system

Source:.own work
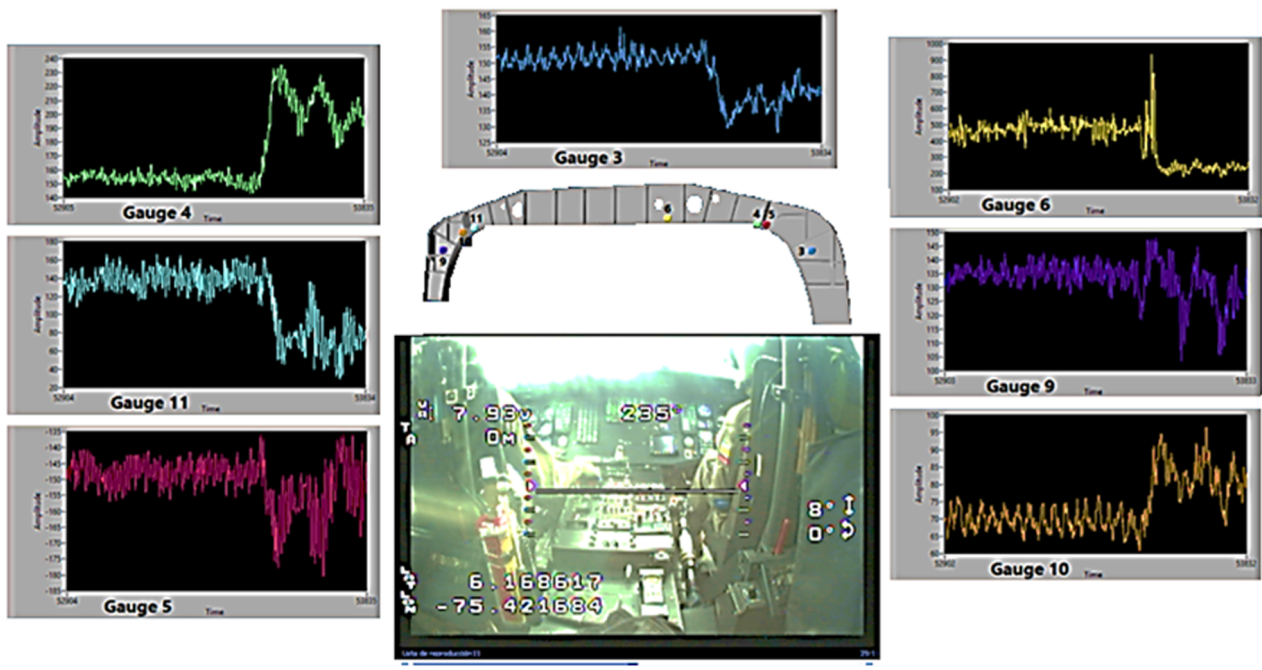

Figure 1b. Data integration result integrated with strain gauge power spectra density Source: Source:.own work

Figure $1 \mathrm{~b}$ shows the flight parameters recorded by the system, integrating gauge data acquisition and the video results of the cockpit and flight control measurements. This data will allow us to relate the aircraft's situation with the gauge output. The 
Data acquisition module MX840 of HBM allows for the recording of data entries to solid-state memory. In this way, it is possible to obtain information about the stresses and the conditions of flight that provoked them at any moment during the flight.

A 3D prototype of the design of the structure was made with CAD software. The model was passed through a stress simulation to ensure there was sufficient support and constraints for the inertial systems that would be used during the testing. The autopilot and the video recording dome were also integrated, along with the stress recording system in a way that guarantees that the recording integrity is in simultaneous inclination with the rotation data of the aircraft during flight maneuvers. The capacity to withstand the loads of the forces of gravity inside the cabin of the aircraft, as described in [34], was taken into account when designing the prototype. Also, systems of anchorage and damping to integrate the systems of inertial data acquisition and vibration migration were included in the design to make sure that data integrity is not compromised during flight-testing of the UH-60 aircraft.

\section{DATA ACQUISITION AND ANALYSIS}

A precise model was needed to make precise measurements and create a precise simulation. To obtain a precise model, the surface of frame 308 was scanned with a 3D scanner. This gave us a cloud of points corresponding to the geometry of frame 308 as shown in Figure 2a.

Because the T-beam is a large structure, it was very important that the scan was performed at the highest resolution possible. To get this resolution, we took measurements of 700 microns with 36 reference objects and obtained measurements of components with the following requirements:

- $\quad$ Acquiring size capacity in the process of scanning and surface lifting.

- Maximum range of accuracy and resolution delivered by the team.

- Design and adjustment of equipment based on the needs of the client.

- Software, which is acquirable and user-friendly, that best fits the resolution of the point cloud.

With the measurements made by the Tarsio 3D Scanner, properly calibrated, a mesh with 317009 triangles was generated on frame 308 to form the solid 3D form of the frame, as shown in the Figure $2 \mathrm{~b}$. This solid is characterized by its high precision, which will allow a simulation of the elements that converge in the areas where deformation and structural fatigue occur. 
This process, as mentioned in the methodology section, is split in two frames: one with 0 hours of use and another with a life of 7500 hours of use in operations with weather conditions set to represent the tropical environment the country is known for.

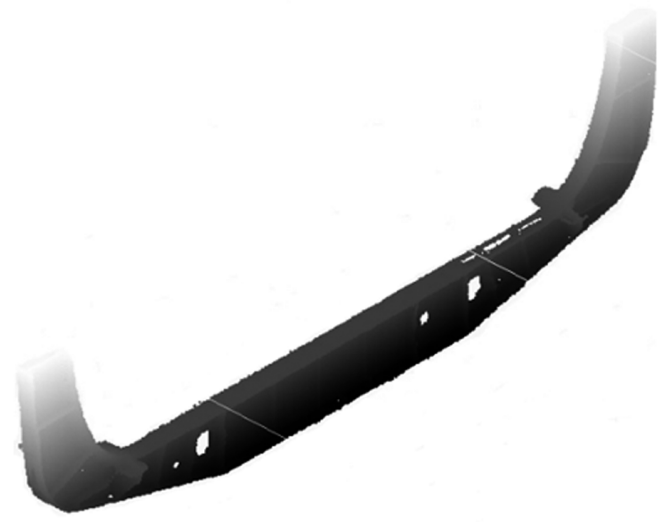

Figure 2a. Point cloud frame 308 Source:.own work

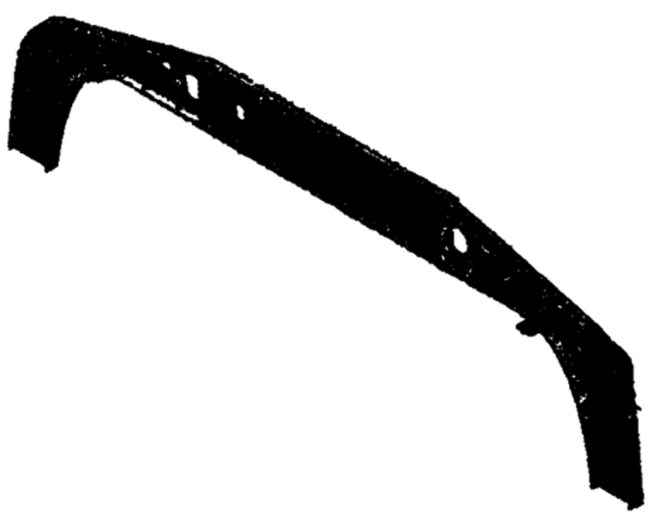

Figure 2b. Point cloud mesh.

Source:.own work

Point cloud comparison: After taking measurements and generating the solids as described previously, the deformation was verified by comparing the surface surveys of the two frames using calibrated equipment that was suitable for the comparison of point clouds. With the point cloud and the mesh developed from the 3D scan process, the capture time, processing time and computational requirements of the analysis were reduced. For mesh convergence, it was necessary to obtain the element numbers in which the results do not vary. This was needed to create an ideal mesh 
with fewer elements and possible nodes. This ideal mesh would avoid increasing the computational cost and produce optimal results as shown in Table 1.

Table 1. Relation between Size/elements/nodes.

\begin{tabular}{cccc}
\hline Size elements & Elements & Nodes & Despl. \\
\hline 1,5 & 521412 & 776658 & 6,202 \\
\hline 2 & 233465 & 357292 & 6,201 \\
\hline 3 & 80126 & 128534 & 6,596 \\
\hline 15 & 3861 & 1226 & 6,421 \\
\hline 30 & 2000 & 669 & 2,609 \\
\hline 90 & 920 & 323 & 2,595 \\
\hline 120 & 780 & 283 & 1,765 \\
\hline
\end{tabular}

Source: own work

In order to determine the variation of the affected area due to the deformation of frame 308, especially the critical areas defined in the inspections, it was found that there is a deformation that exceeds the creep limit described in [23]. The plastic deformation is shown in Figure 3. According to the analyses and one of the experienced maintenance technicians, it is likely that this is caused by the loads in the beams that support these components. These loads are produced by the weight of the engine and the transmission of the aircraft [24]. For modelling and comparison, Cloud Compare ${ }^{\circledR}$ software was used. This gave us a display of the frames at 0 flight hours and at 7500 hours of flight as shown in Figure 3.

For the modelling of the main beam and its components, Catia CAD software of Dassault Systems ${ }^{\circledR}$ was used. The mesh was generated using the gathered information from the survey of the previously described surface and the data product of measurements with Radios radus gauge set and Vernier calipers. This was done by modelling the geometry of the main beam of the UH-60 aircraft and comparing the data generated by the model with the data measured with a calibrator. This information was enough to create the final model of the main beam with its anchorages set up in accordance with the recommendations of [32]. This model had the holes, rounding, thicknesses and the profile of the beam which would be subjected to study in the finite element software. The results are shown in Figure 4. 


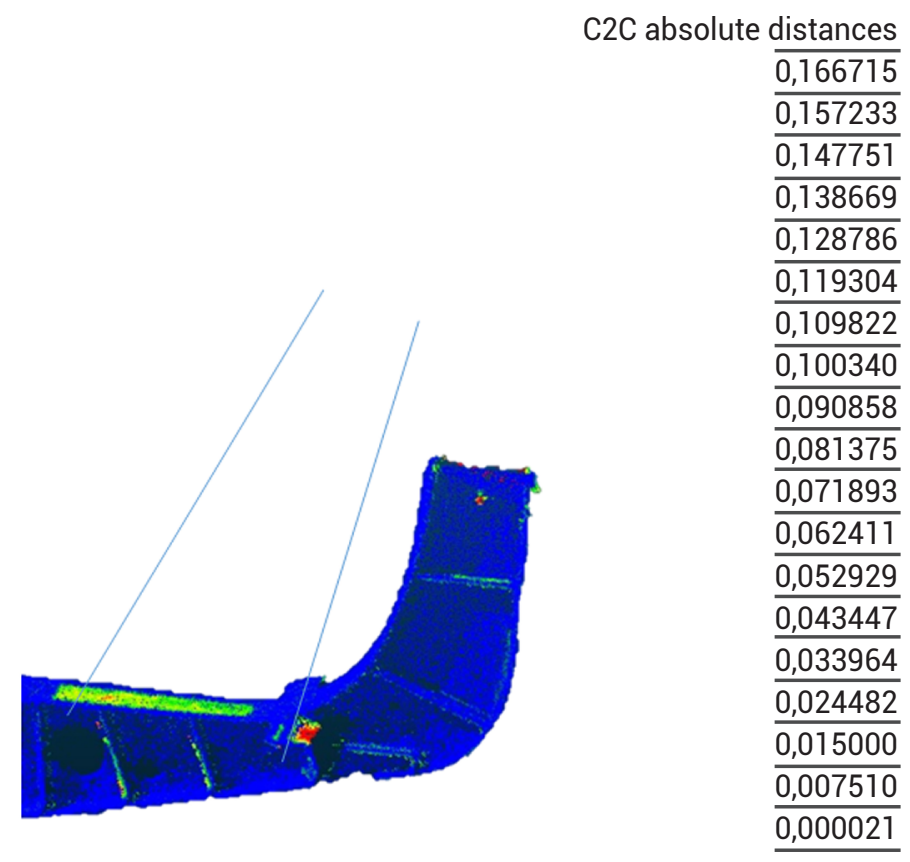

Figure 3. Comparison cloud to cloud of Frame 0 points and 7500 flight hours. Source: own work

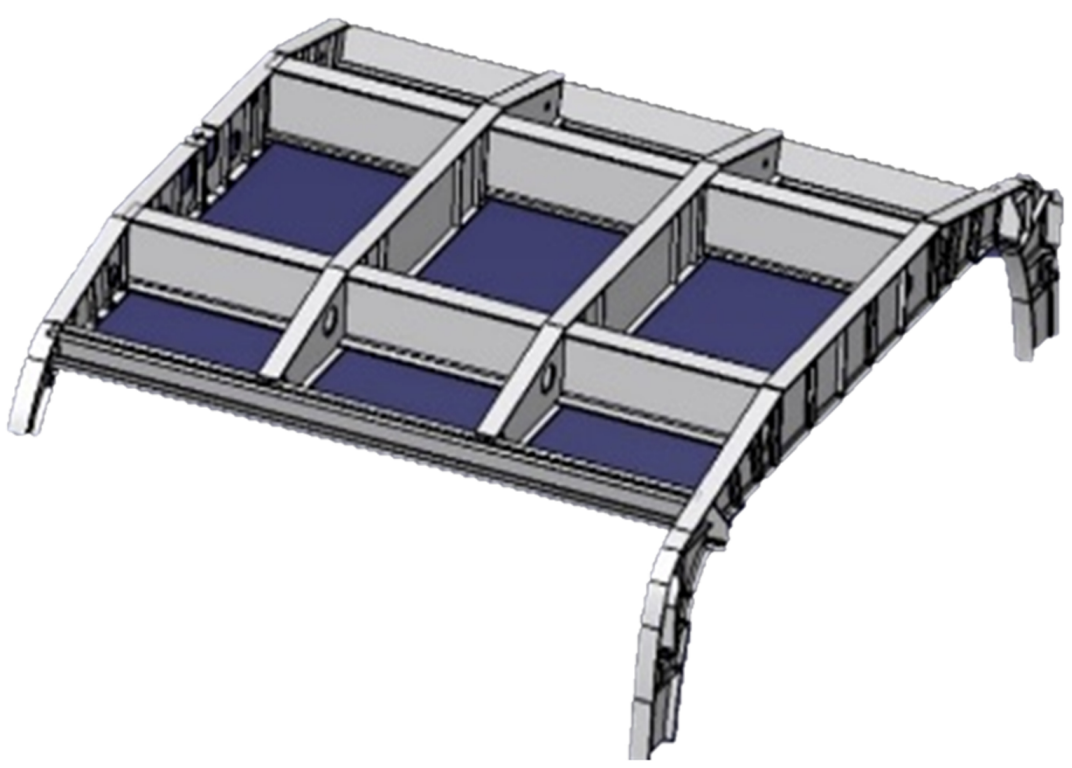

Figure 4. Modelling and assembly in CAD Catia.

Source: own work 
Traction test. For the acquisition of structural deformation data of the UH-60 aircraft and analysis of specimens, beams or parts of the beam that had already fulfilled their useful life in accordance with the manufacturer's manual and the Air Force maintenance manual were used. The beams also had to be available and made of the original material. Materials were extracted to carry out tests to measure the physical and mechanical properties of the material that the studied element is composed of. This allows us to extract these properties in real conditions while still complying with the guidelines that are detailed in ASTM E8 [21] for non-ferrous materials as shown in Figure 5.

The measurements of the tensile specimen were obtained using the thickness of certain areas of the beam and the specifications of ASTM E8. The measurements were used in the programming of the trajectories in G-code. The G-code was later fed to an Electro cutting machine which used Wire Erosion. Since traction specimens must be obtained with the measurements previously defined, cuts were made to extract the specimens that would then go through Wire Erosion cutting. For this process, the material must be in its purest state, i.e. the material must be without paint or other elements. This is because they interfere with conductivity needed during the cutting process, and the test tube needs to be flat because of the fastening form of the cutting area of the machine. Once the prepared specimens have been obtained, it is necessary to carry out traction and torsion measurements using pre-calibrated and certified equipment. In the process of traction, the measurements of the deformations and displacements of the material are made according to [23].

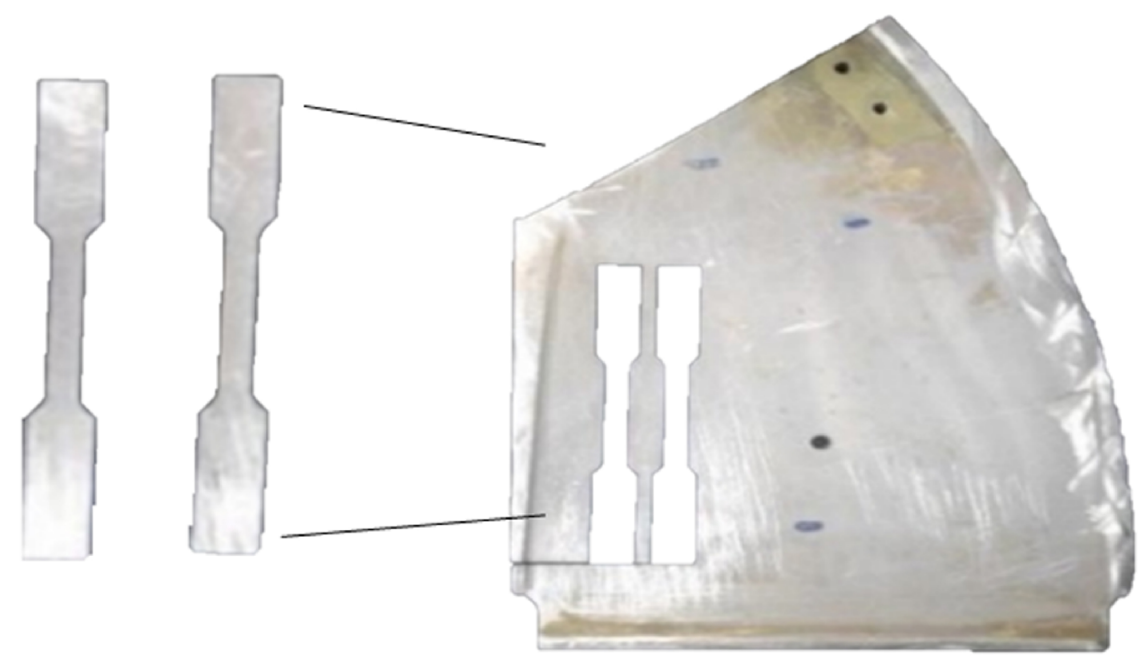

Figure 5. Cutting of specimens, frame 308 material. Source:.own work 
The specimens were cut in the direction shown and within the available cutting space. Cutting within this space allowed for the removal of the specimen. Also, the direction of the grain was not identified, because the manufacturing process of frame 308 is a metal forging process. Software for the analysis of Materials Trapezium X was used to generate a visual and benchmark analysis of the results from the test using the engineering curves described in [33]. Similar processes are also used to analyze elasticity, creep, area reduction, stresses and unit deformation. This information is required by the finite element software to perform the simulation and analysis.

The results allow us to establish a reference point, identify the limit of elastic deformation of the 308 frame and identify, by means of the finite element simulation, the displacement, cracking and fatigue in the stress concentration zones.

Figure 6 shows these results and the results of actual tests based on laboratory results. Getting creep values makes it possible to calculate the creep limit that the material can support for the test conditions.

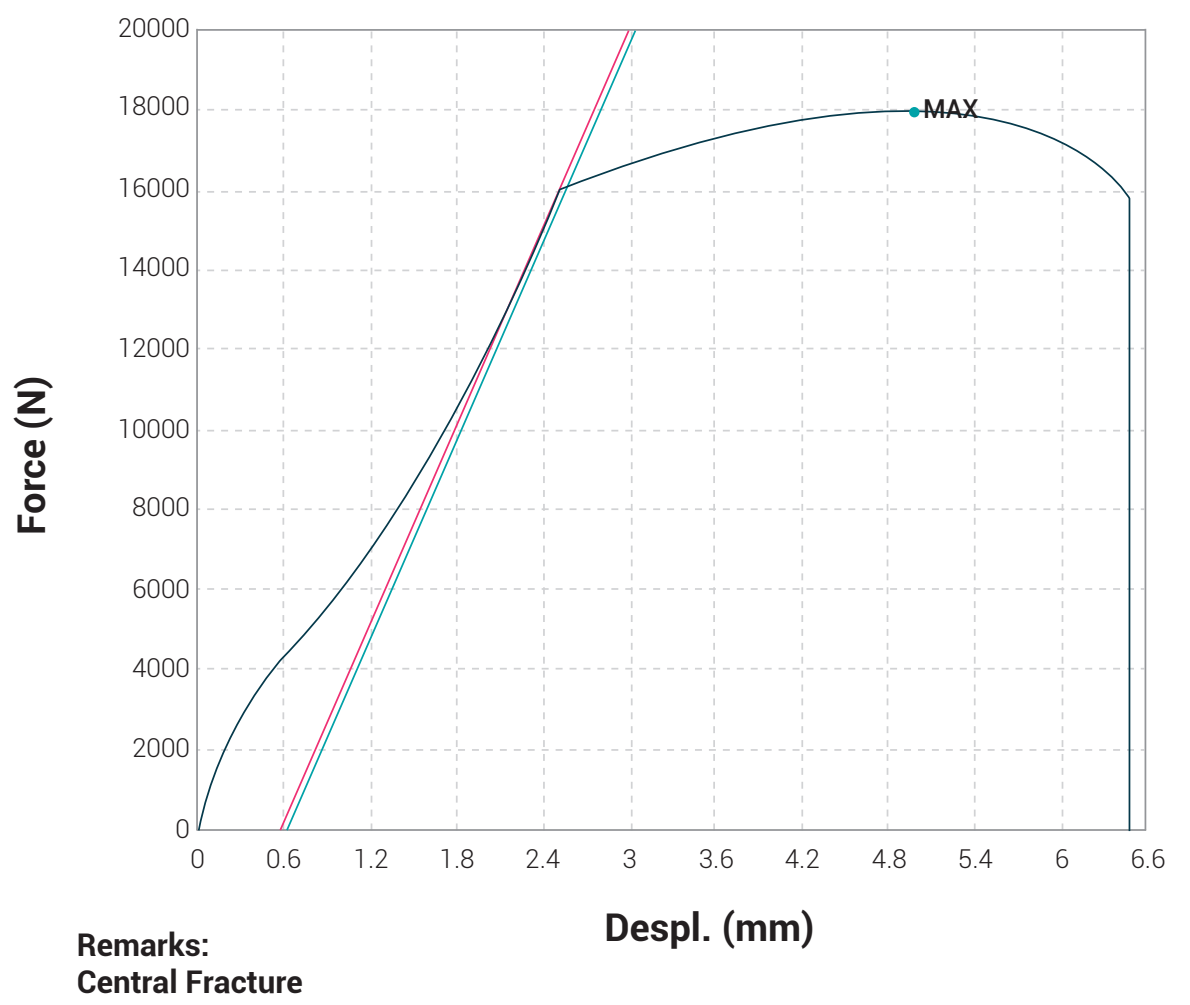

Figure 6. Traction test result graph. Source:.own work 
In order to simulate the behavior of the main structure of the $\mathrm{UH}-60$, finite element techniques are used. Abaqus 6.12-1 software of Dassault Systems ${ }^{\circledR}$ used assorted data in its simulation including the mechanics and geometry of the material, data that was obtained in the ways detailed previously, and techniques to increase the precision with reference points that define the area of frame 308 where the fasteners that interact in the anchorage are located, as shown in Figure 7. The boundary conditions are the loads the structural system was subjected to. These loads were based on the information collected and data from the aircraft's technical manuals.

The model used a refined mesh with 451770 tetrahedral elements. This mesh allowed for a processing time and simulation conditions according to the parameters required. Figure 8 shows the solid model in Abaqus and the refined mesh.

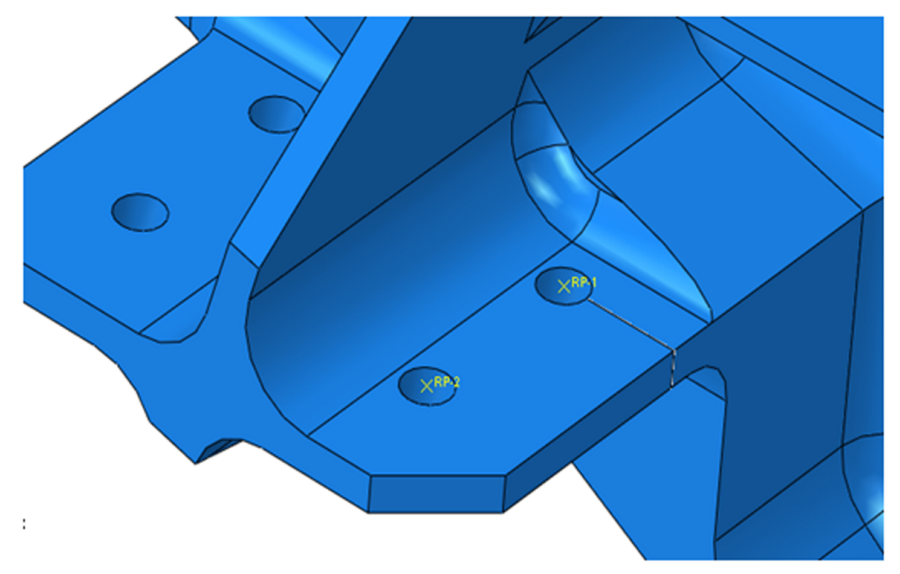

Figure 7. Anchorage model in Abaqus.

Source: own work

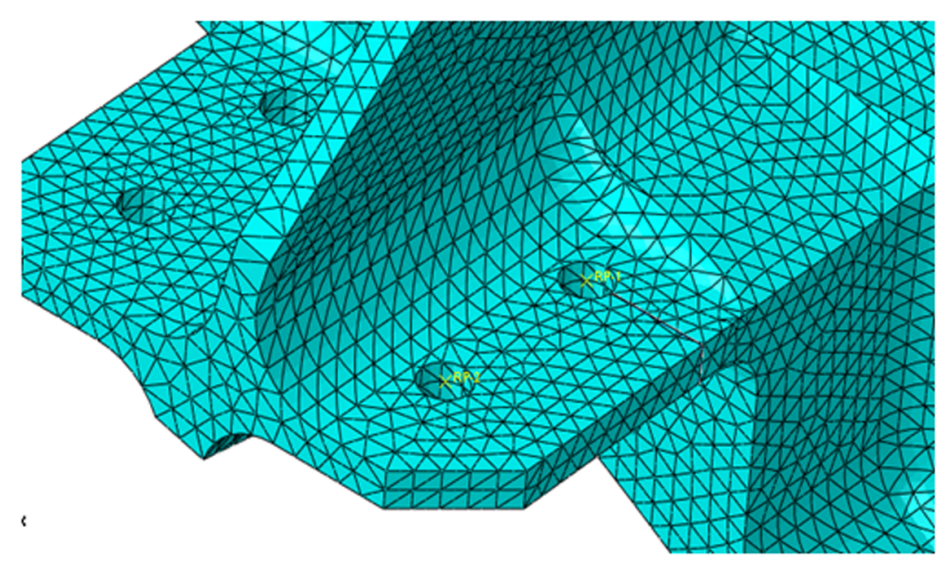

Figure 8. Mesh model in Abaqus.

Source: own work 
This type of technology, also known as extended finite element methodology, could simulate the cracking that occurs in the areas of stress concentration in aeronautical structures which are caused by, in the case of frame 308 , discontinuities near holes and oversizing in the Cold Working process required for proper installation of the fastener as described in the manufacturer's manual. The extended finite element analysis procedure offers an alternative set of results for comparison. The alternative comes with a history of damage from traction separation laws including the evolution of the damage, displacement of the fault and concentration of stresses.

\section{STUDY OF LOADS AND STRESS CONCENTRATIONS}

In the section with the highest micro-deformation, found in the first phase of the project, the value of the load exerted on the anchoring area of frame 308 was identified. This was done to quantify it and make a comparison of the changes each time the material is deformed after the Oversize procedure, detailed in the manufacturer's manual. In order to set the loading location points in the Abaqus finite element software, the statically undetermined double-recessed beam model was used with multiple point loads corresponding to equations of Resistance of materials for analysis of isostatic and hyperstatic beams. This allows us to compare the calculations and graphs of shear stress and momentum according to [28], where it is observed that the shear force varies with respect to the horizontal distance and the rate of change is described by the slope with respect to the length. These are of course set in accordance with the geometry of frame 308 , its main points of attachment and therefore areas of concentration of loads where beams are located as multiple point loads.

The exchange and summation of forces is described in Figures 9 and 10. 


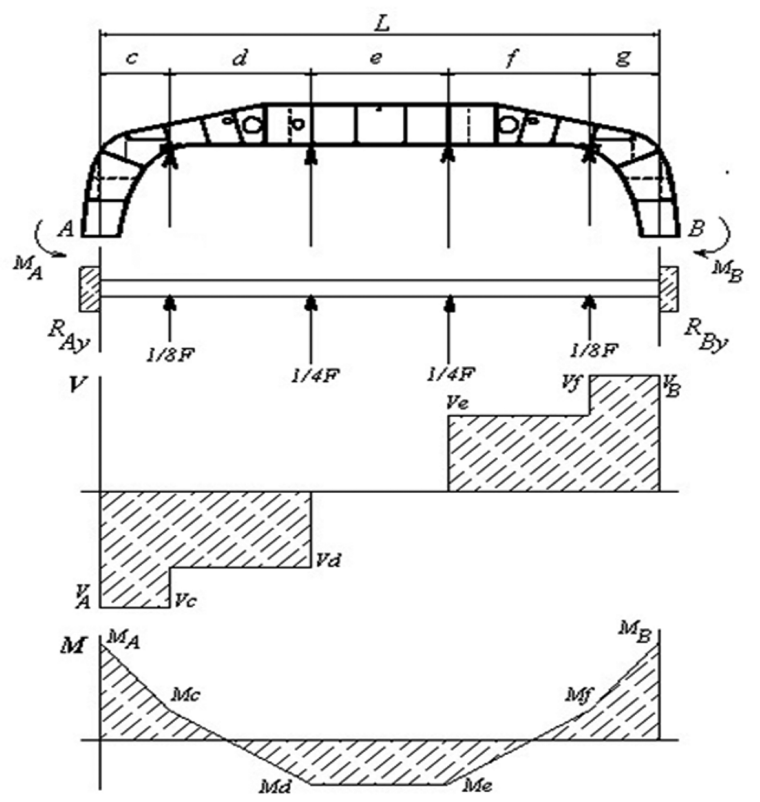

Figure 9. Shear Diagram and Bending Moment along the YZ plane. Source: own work

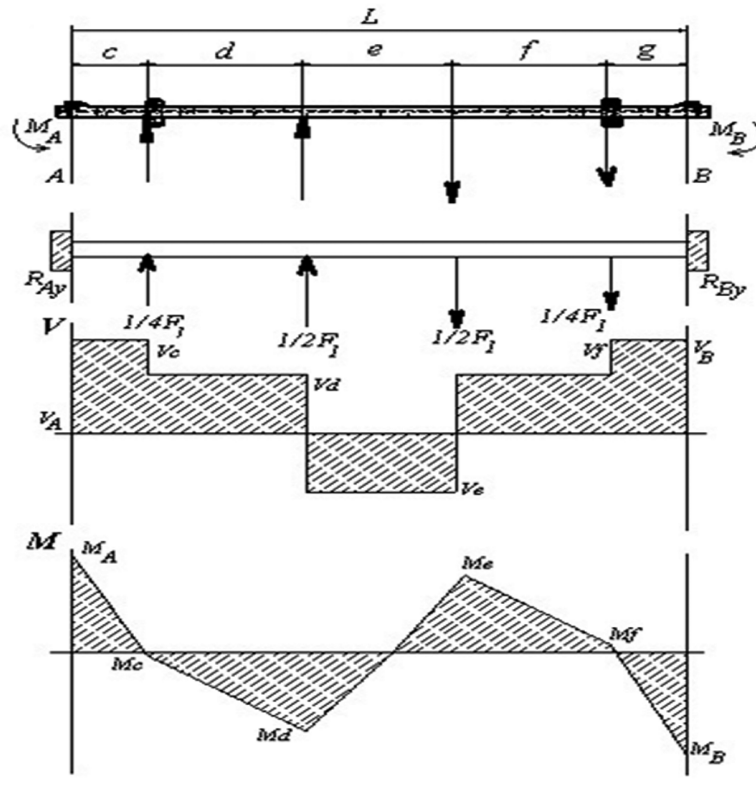

Figure 10. Shear diagram and Bending moment along the XY plane. Source:.own work 
Later, a measurement of the affected area anchorage is shown in Figures 11of frame 308was carried out using the bibliography of resistance of the materials. The specimen's bibliographies are composed of the data provided by tests and the data acquisition systems. The fatigue of Material photographic records were used to analyze the anchorage. The concept of concentration of stresses described in [27] and the equations for quantification of the stress concentration, by discontinuity of the Material by holes in the plate, were used to calculate the maximum strength.

- $\mathrm{R}=$ Orifice Radius

- $\mathrm{D}=$ difference in magnitudes due to the absence of material

- $\quad \mathrm{R} / \mathrm{d}=$ Relation by which, we will know the Factor of concentration of stresses $\mathrm{K}$, by means of the graph

- $t=$ thickness of the plate.

- $\quad$ NET area $=\mathrm{dxt}$

- $\Sigma_{-}$Max $=$is obtained from the measurements of PHASE 1 of the project, effect of the flight maneuvers on the structure of the aircraft UH-60.

- $\quad P \max =$ Maximum strength is acquired by means of the equation:

$$
P_{\max }=\frac{A_{\text {neta }} \sigma_{\max }}{K}
$$

Then, Equation 4 used the point of concentration of stresses by the orifice and parameters whose values were obtained from the graphs of stress concentrations. The case this equation was applied to is described in [27].

Based on the observations and in accordance with the manuals and procedures of internal maintenance of the FAC and other references such as [25] [32] [6], it was established that a procedure called Oversize is carried out during maintenance. This procedure is implemented in the air industry and supported in engineering studies of aircraft structures where the diameter of the manufacturer's mandated fastener is increased. This process is described in the aircraft manual. It is accomplished using a Cold Working rectifier, where the material is removed until the crack is gone, and residual stresses are induced in the material. This improves the material's performance under tensile stresses.

The oversize is made in increments of $1 / 64$ " or $0.4 \mathrm{~mm}$ in diameter. Only one oversize is allowed at a time with up to three times maximum. This is specified by the manual. A part of the procedure is installing and verifying. This is done with torque calibration and revision dates provided by a competent authority. This is done to satisfy a safety measure issued by the manufacturer of the $\mathrm{UH}-60$. 
From the measurements obtained by gauges, along with deformation values in microns in Phase 1 of the project described in [35], we proceeded to analyze the stresses and compression forces in the affected zone of frame 308. This gave us a visualization and an understanding of the load conditions which frame 308 was under.
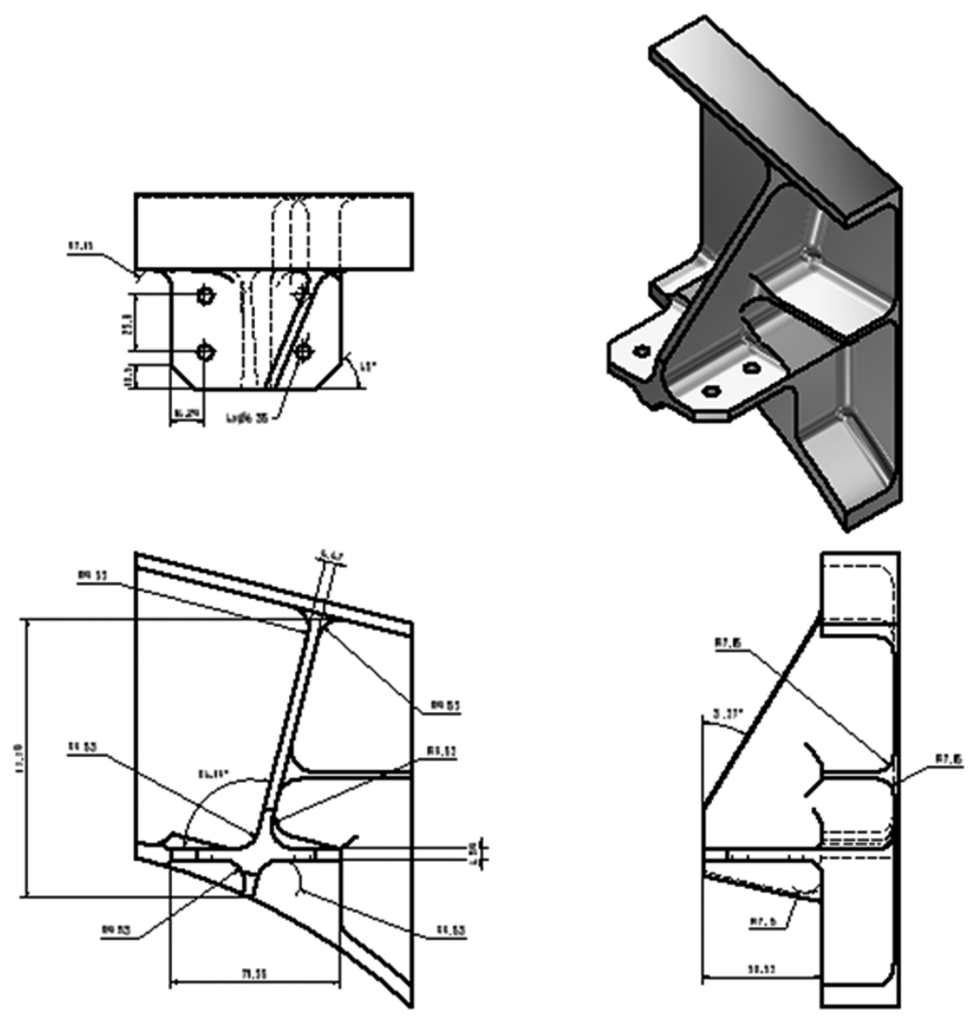

Figure 11. Anchorage measurements. Source: own work

\section{RESULTS}

The first step, when gathering the results, was to determine whether or not the hole oversize process affects the strength of the structure. The results were quantified based on measurements taken during Phase 1 [36] of this project called "Effect of the maneuvers on the UH-60 Aircraft Structure". By calculating the force exerted on the anchorage of frame 308, results were obtained for the concentration of stresses generated by discontinuities in the material near holes where the Hi-Lock fasteners were installed. The numerical results show a weakening of the material during the procedure where the diameter of the whole is increased by Oversize. It quantified the 
reduction of load capacity at the specific point of the anchorage of frame 308. This is described in Table 2, where it generates cracking and damage in the anchorage of frame 308 .

In Table 2, the correlation between the weakening of the material whilst incrementing the diameter of the Oversize holes and the decrease of force applied in this zone of the anchorage can be observed. The force is also displayed for both "supported with holes" and "without holes" conditions, especially in the stress concentration factor and in the Force $P$.

Table 2. Table of stress concentration results.

\begin{tabular}{|c|c|c|c|c|}
\hline Dimensions & $\begin{array}{l}\text { Diameter } \\
\text { Nominal } \\
\text { (M) }\end{array}$ & $\begin{array}{l}\text { First Oversize } \\
\text { (M) }\end{array}$ & $\begin{array}{l}\text { Second } \\
\text { Oversize } \\
\text { (M) }\end{array}$ & $\begin{array}{c}\text { Third } \\
\text { Oversize } \\
\text { (m) }\end{array}$ \\
\hline Hi-Lock diameter. & 0,00635 & 0,00675 & 0,00715 & 0,00755 \\
\hline Increase Oversize diameter, [m] & 0,0004 & 0,0004 & 0,0004 & 0,0004 \\
\hline Radio $[\mathrm{R}]$ & 0,003175 & 0,00337 & 0,003575 & 0,00377 \\
\hline Width of the piece. [m] & 0,02381 & 0,02381 & 0,02381 & 0,02381 \\
\hline Difference (d) [m] & 0,01746 & 0,01706 & 0,01666 & 0,01626 \\
\hline$r / d$ & 0,181844 & 0,19783 & 0,214585 & 0,232164 \\
\hline Concentration factor of stress, $\mathrm{K}$ & 2,52 & 2,51 & 2,48 & 2,46 \\
\hline Max Stress, $\sigma$ max., [KPa]. & 31500 & 31500 & 31500 & 31500 \\
\hline Thickness, t [m] & 0,00516 & 0,00516 & 0,00516 & 0,00516 \\
\hline Net Area, $A\left[m^{\wedge} 2\right]$ & $9,00 \mathrm{E}-05$ & $8,8 \mathrm{E}-05$ & 8,59E-05 & 8,39E-05 \\
\hline Force, $\mathrm{P}[\mathrm{KN}]$ & 1,12617 & 1,10475 & 1,09190 & 1,07434 \\
\hline Full section, [m] & 0,02381 & 0,02381 & 0,02381 & 0,02381 \\
\hline Full Area, $\left[m^{\wedge} 2\right]$ & 0,00012286 & 0,0001229 & 0,00012286 & 0,00012286 \\
\hline Force without Discontinuity, F [KN] & 3,8700774 & 3,8700774 & 3,8700774 & 3,8700774 \\
\hline Difference of Forces, F-P, [KN] & 2,7439074 & 2,7653235 & 2,778175626 & 2,79572764 \\
\hline
\end{tabular}

Source: own work

The results of Table 2 were obtained using real measurements from the anchor of frame 308 and measurements from the first phase of the project. This data was compiled with manufacturer-allowed information. Then, using equations and graphs, the factor of concentration and the force exerted in a discontinuity of the material (hole) was obtained. These will be used in a finite element simulation.

Post-processing reveals the stresses that are generated in the structure. These were the results obtained in the actual traction test carried out within the investigation. 
Cracking in the stress concentration zones can also be seen. The displacement produced by the stresses, with an increased scale factor to visualize the behavior of the crack at this point, is shown in Figures 12 and 13.

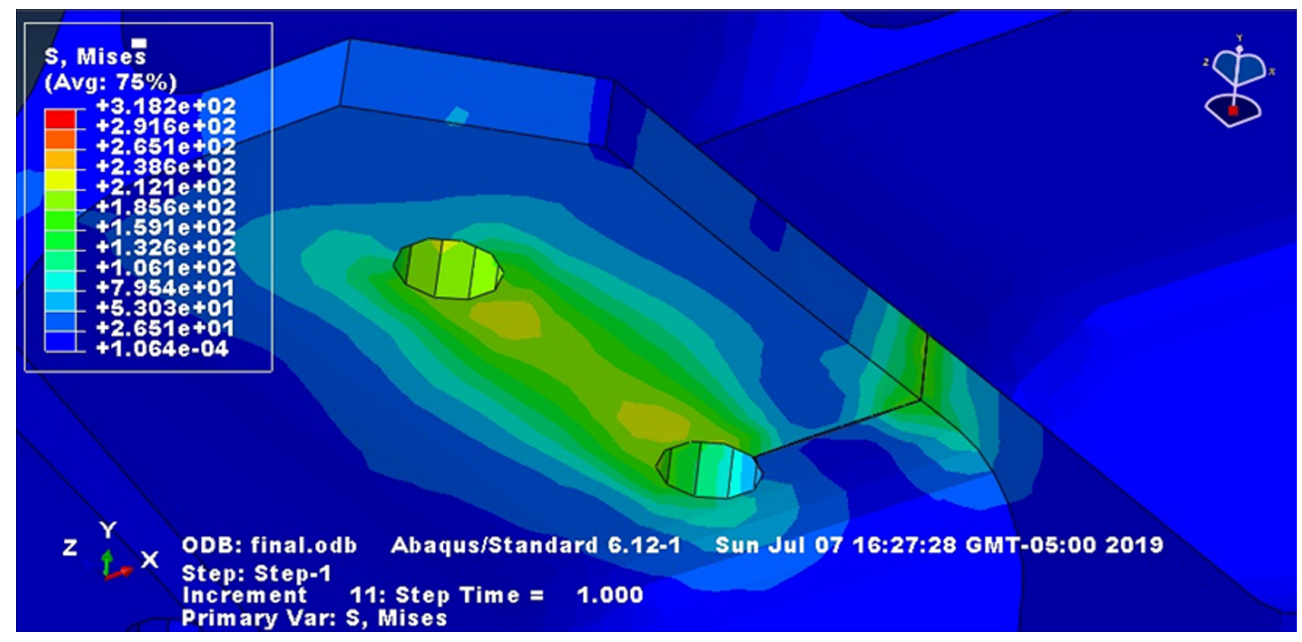

Figure 12. Result of Von Mises tension of the anchor.

Source: own work

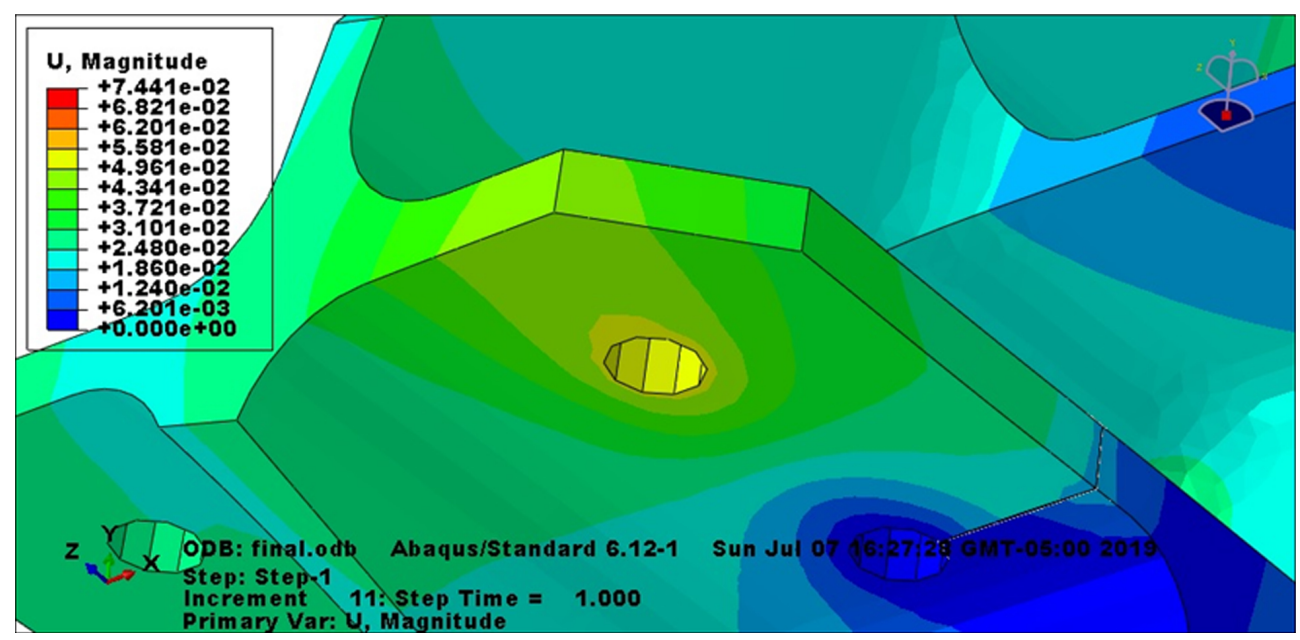

Figure 13. Anchor displacement result.

Source: own work

After the cloud-dotted spot of the surface lift process with a 3D scanner has been found, the smaller and more complex measurements with precision measuring elements need to be checked and calibrated to minimize the margin of error in the model used in finite element modelling and simulation. 
With the mechanical properties of the material, boundary conditions and applied loads, these results allow us to visualize the relative cracking of the material of frame 308 with the software simulation instead of only with the tensile test performed. In specimens based on the ASTM E8 standard, the displacement due to the force applied and the Von Mises stresses are related to determine the safety factor of the anchorage. The safety factors must be within the limits established by the original equipment manufacturer according to the applied loads during flight maneuvers.

\section{CONCLUSIONS}

Measuring surfaces with a 3D scanner can result in more precise measurements of large components. Also, 3D scanners can detect deformations that, at first sight, are not possible to identify. This is a safe and precise way to gather the data necessary for a Simulated Inertial Measurement Unit (SIMU) and analysis by means of the finite element method.

The finite element software, in addition to other complementary software, allowed for modelling and simulating conditions that worked along with certain methodologies and analyses to find correlations, the study of components that converge at frame 308 of the $\mathrm{UH}-60$, or the study of other parts with high stresses and criticality levels.

However, simplifying the model of frame 308 was necessary to obtain any results from the simulation. This simplification focused on the points of interest where most of the cracks are generated and therefore most of the fatigue. A machine with higher than $8 \mathrm{~GB}$ of physical memory is required for processing data in a refined mesh. Bear in mind that the dimensions applied when modelling frame 308 are to scale with the aircraft, which means that the assemblies were set up with the other structural elements interacting with frame 308 in another part module format.

Structural health monitoring serves to predict, prevent and provide integral care for aircraft with the help of sensors [18]. This analysis will allow aircraft maintenance technical personnel to make decisions. They will be able to take preventive and pertinent measures after the inspection, after the plane has been in an operation, or whilst it is in service.

The XFEM helps to observe the behavior of mechanical elements, in the case that there is no approved device available for testing in the aerospace sector [13]. 


\section{Acknowledgments}

The research presented in this paper was made possible by the Sponsorship of Colciencias and the support of the Center for Aerospace Technological Development for Defense-CETAD of the Colombian Air Force, which contributed to the loan of its laboratory, equipment, and its main asset, human resources.

Thanks to the experienced military technical staff of the CACOM-5 Technical Group:

- MY. Hugo Herrera

- Chief Technician (R) Adolfo Herrera.

- Chief technician Holman Ramos.

- Chief Technician Edinson Andrade.

- Chief Technician Idelfonso Bustos

- Thanks to the civilian staff of the Engineering Section of the Technical Group-GRUTE of CACOM-5:

- Engineer. Luis David Arboleda Ortiz.

\section{References}

[1] A. Faccenda, R. Canadale, and S. Sweikar, "Integration of Externally Carried Weapon Systems with Military Helicopters (L'Integration des Systemes d'Armes Transportes en Charge Externe sur les Helicopters Militaires)," 1990, pp. 58-65.

[2] Army Science, Conference Proceedings, $12-15$ June 1990, vo. 2, 1990, pp. 474-486.

[3] Helicopter/Weapon System Integration (l'Integration des systems d'armes des helicopters), 1997, pp. 36-56

[4] Williamsburg, B. D. Davidson, J. G. Ratcliffe, and M. W. Czabaj, Proceedings of the American Society for Composites, Thirty-First Technical Conference: September 19-21, 2016, Williamsburg Lodge, Williamsburg, VA. .CD

[5] S. K. Yang and T. S. Liu, "State estimation for predictive maintenance using Kalman filter," Reliab. Eng. Syst. Saf., vol. 66, no. 1, pp. 29-39, 1999. [Online]. doi: http://dx.doi.org/10.1016/ S0951-8320(99)00015-0 
[6] Department of the Army Headquarters, General aircraft maintenance manual. 1970, CH4-p, pp. 474-486.

[7] C. L. Kee, "Military Operations Research Society Symposium (70th): Military Operations Research at the Next Frontier. Held at Fort Leavenworth, Kansas on 18-20 June 2002. Final Program and Book of Abstracts," 2002.

[8] J. I. Group, “UH-60S ORDERED,” Jane’s Def. Wkly, 1990.

[9] J. I. Group, "Switchboards in the sky," Int. Def. Rev., 2001.

[10] G. R. Humphrey and R. W. Martin, "1998 Technology Showcase. JOAP International Condition Monitoring Conference," 1998, pp. 215-224

[11] "dod Modeling and Simulation (M\&amp;S) Glossary," 1998, pp. 8-182

[12] G. S. Frankel, "Corrosion Degradation of Coated Aluminum Alloy Systems through Galvanic Interactions," 2017, pp. 2-9

[13] A. D. 222599 Number, S-70A-9 Black Hawk Helicopter: Internal Cracking Investigation. Department of Defense, 1997, pp. 65,67,105,116.

[14] M. R. Mofakhami and J. Pinsonnault, "A prospective for Structural Health Monitoring system implementation on civil aircraft," 2011 Cansmart Cinde Izfp, no. November, pp. 1-7, 2011.

[15] U. G. Goranson, "Fatigue issues in aircraft maintenance and repairs," Int. J. Fatigue, vol. 20, no. 6, pp. 413-431, Jul. 1998. doi: 10.1016/S0142-1123(97)00029-7

[16] B. Kamsu-Foguem, "Knowledge-based support in Non-Destructive Testing for health monitoring of aircraft structures," Adv. Eng. Informatics, vol. 26, no. 4, pp. 859-869, 2012. [Online]. doi: 10.1016/J.COMPSTRUCT.2015.02.080

[17] A. Katunin, K. Dragan, and M. Dziendzikowski, "Damage identification in aircraft composite structures: A case study using various non-destructive testing techniques," Compos. Struct., vol. 127, pp. 1-9, Sep. 2015. . [Online]. doi: 10.1016/J.COMPSTRUCT.2015.02.080

[18] F.-K. Chang, United States. Air Force. Office of Scientific Research., United States. Army Research Office., and National Science Foundation (U.S.), Structural health monitoring 2003: from diagnostics \&amp; prognostics to structural health management: proceedings of the 4th International Workshop on Structural Health Monitoring, Stanford University, Stanford, CA, September 15-17, 2003. Destech Pub, 2003, pp. 16,20,34 
[19] X. J. Sun Bo, Kang Rui, "Research and application of the prognostic and health management system," Systems Engineering and Electronics," 2007. [Online]. Available: http://en.cnki.com. cn/Article_en/CJFDTOTAL-XTYD200710041.htm.

[20] M. Q. Le et al., "Review on energy harvesting for structural health monitoring in aeronautical applications," Prog. Aerosp. Sci., vol. 79, pp. 147-157, Nov. 2015. [Online]. doi: 10.1016/J. PAEROSCI.2015.10.001

[21] A. Standard, "Standard test methods for tension testing of metallic materials metric," Annu. B. ASTM Stand., vol. 3, pp. 57-72, 2004. [Online]. doi: 10.1520/E0008

[22] ASM International, ASM International Handbook Committee (1992). Properties and Selection Nonferrous Alloys and Special - Purpose Materials.ORG: Autor.pp451-462., vol. 2. 1992. [Online]. doi: $10.1007 / s 004310050884$

[23] D. R. Askeland, "Ciencia e Ingenieria de los Materiales - Donald Askeland - 3edicion.pdf," p. 737, 1998.

[24] D. O. T. A. Headquarters, "Chapter 6 Maintenance Instructions," In Tm 1-1520-237-23-6 Aviation Unit And Intermediate Maintenance For Army Models Uh-60a, Uh-60l, Eh-60a, Uh-60q And Hh60l Helicopters, no. April, 2006, pp: 6,114,115,180,181,189-195

[25] Fuerza Aerea Colombiana, "Manual de Mantenimiento Aeronáutico-MAMAE," Man. Manten., vol. 4.1.1-0, pp. 307-309, 2016.

[26] Fuerza Aerea Colombiana, Manual Para El Transporte De Mercancías Peligrosas Por Vía Aérea Para La Aviación De Estado. 2016, pp:36-40.

[27] R. K. J. Budynas, “Diseño en Ingenieria Mecanica de Shigley,” p. 933-956, 2008.

[28] B E. Russell Johnston and Ferdinand P. Beer, Mecánica Vectorial Para Ingenieros. 2007, pp. 285-345.

[29] K. A. Latorella and P. V Prabhu, "A review of human error in aviation maintenance and inspection," Int. J. Ind. Ergon., vol. 26, no. 2, pp. 133-161, Aug. 2000. [Online]. doi: 10.1016/ S0169-8141(99)00063-3

[30] A. Unit, I. M. For, G. Information, and E. Description, TM 1-1520-237-23-1 Aviation Unit And Intermediate Maintenance For Equipment Description And Data, no. April. 2006.pp 72-74 
[31] Department of Army, TM 1-1520-23-10 “Operator's Manual for UH-60A UH-60L EH-60A," no. October, 1996, pp. 384,400.

[32] A. A. A. M. Command, "Dmwr 1-1520-237-3 Airframe Depot Maintenance Work Requirement Containing For Army Models Uh-60a, Eh-60a , And Uh-60l Helicopters Nsn 1520-01-035-0266 NSN 1520-01-082-0686," no. January 2004, 2003, pp103-111.

[33] D. N. E., Mechanical Behavior of Materials. Norman E.Dowling, 2012, pp. 148-154

[34] Department of Army, "Headquarters, Department of the Army. (2006) Aviation unit and intermediate maintenance for army models UH-60A, UH-60L, EH-60A, UH-60Q and HH- 60L helicopters Chapter 1 General TM 1-1520-237-10,” pp. 72,74,103, 2006.

[35] CETAD, "Informe final proyecto 40176," 2014. 